\title{
SAJÁTOS NEVELÉSI IGÉNYŰ (SNI) ÉS TÖBBSÉGI TANULÓK TESTALKATI MUTATÓINAK ÉS MOTOROS KÉPESSÉGEINEK ÖSSZEHASONLÍTÓ VIZSGÁLATA A NETFIT RENDSZERBEN
}

\section{Szerzők:}

Erdei Norbert

Móra Ferenc Általános Iskola, Budapest
Keresztesi Katalin

Debreceni Egyetem

Szabó Eszter

Kaposvári Egyetem

Mező Ferenc

Debreceni Egyetem

Schéder Veronika

Debreceni Egyetem
Szerző e-mail címe: erdei.norbert.70@gmail.com
Lektorok:

the

(1)

Erdei Norbert (2015): Sajátos nevelési igényü (SNI) és többségi tanulók testalkati mutatóinak
és motoros képességeinek összehasonlító vizsgálata a NETFIT rendszerben. Különleges
Bánásmód, I. évf. 2015/3. szám, 57-66. DOI 10.18458/KB.2015.3.57

\begin{abstract}
Absztrakt
A sajátos nevelési igényü tanulók (SNI) a magyar oktatási rendszer résztvevői. E tanulmány célja az SNI tanulók és a többségi tanulók teastalkati mutatóinak és motoros képességeinek összehasonlítása. Minta: $n=160$ fö (80 SNI és 80 többségi tanuló) 1-8. évfolyamos általános iskolai tanuló. Módszer: a testalkati mutatók és a motoros képességek felmérése a magyar Nemzeti Egységes Tanulói Fittség Teszt (NETFIT) rendszeren alapult. Eredmény: sokkal nagyobb hangsúlyt kell fordítani az SNI tanulók testnevelés óráira, mert fizikumok mutatói és motoros teljesítményük szignifikánsan rosszabbak, mint a többségi tanulóké.
\end{abstract}

Kulcsszavak: SNI, sajátos nevelési igényü tanulók, NETFIT, összehasonlító vizsgálat

Diszciplinák: pedagógia, gyógypedagógia

\begin{abstract}
COMPARATIVE STUDY OF BODY TYPE INDEXES AND MOTORIC ABILITIES OF STUDENTS WITH SPECIAL EDUCATIONAL NEEDS (SNE) AND MAINSTREAM STUDENTS BY NETFIT SYSTEM

Students with special educational needs (SEN) are participants of the Hungarian educational system. The goal of this study is to compare the body type indexes and motoric abilities of SEN students and mainstream students. Sample: $n=160$ persons ( 80 SEN students and 80 mainstream students) from 1-8 grades of elementary school. Method: the survey of body type indexes and motoric abilities physical skills was based on the Hungarian NETFIT system (NETFIT is a Hungarian acronym of the National Unitary Student Fitness Test).
\end{abstract}


Results: much more emphasis should be given to physical education lessons of SEN students, because their physique indicators and motoric performances are significantly worse than mainstream pupils'.

Keywords: students with special educational needs, NETFIT, comparative study

Disciplines: pedagogy, special education

Az Európai Közösségek a nyolcvanas évek végén kezdték el azt az átfogó folyamatot, amelynek elsődleges célkitüzése a fogyatékossággal élők társadalmi integrálása. Magyarország oktatáspolitikájának része az Európai Unió által kidolgozott oktatási-nevelési program. Megfogalmazódott ugyanis, hogy a fogyatékossággal élők problémáját kiemelt ügyként kezelve mindenhol egyértelmüen és határozottan kezeljék - azon területeken (beleértve Magyarországot is), ahol a sokféleség és változatosság jellemző -, az integrációt tekintve oktatáspolitikai célként. Ezen keretek közt, egy elképzelt skálán jól megfigyelhetővé válnak az integráció eltérő mértékei. További célként tekintenek az integráció társadalmi megítélésének kezelésére: az oktatás feladatává tüzte ki a fogyatékossággal élők elfogadását, hiszen a felnőtt társadalom is akkor válik befogadóvá, ha ennek alapjait már gyermekkorban lerakták.

Az UNESCO 1994-ben rögzített szalamankai ajánlása és cselekvési tervezete szerint a sajátos nevelési igényü tanulók oktatása nem fejlődhet tovább szegregált formában. Egy átfogó oktatási stratégiára, és egy új társadalmi és közgazdasági politikára van szükség. Ez pedig fontos reformokat igényel az iskolaszervezésben és az oktatáspolitikában. Ez a dokumentum egy világméretü konszenzus eredményét mutatja be a sajátos nevelési igényü tanulók oktatásának jövőjéről.

Alapelve inkluzív (befogadó) oktatáshoz való közeledés, az iskoláknak képessé kell válniuk minden gyermek, de különösen a sajátos nevelési igényü gyermekek szükségleteinek kielégítésére (Salamanca Statementon Principles, Policy and Practicein Special Needs Educations UNESCO 1994, 3). Ezzel a rendelkezéssel - amennyiben teljesen megvalósulna valóban minden gyermek már életének az elején megkapná a lehetőséget, hogy teljes jogú tagja legyen a társadalomnak.

\section{Sajátos nevelési igényü (SNI) tanulók}

A Nemzeti Köznevelésről szóló 2011. évi CXC. törvény 4. §-ának 25. pontja szerint sajátos nevelési igényü gyermek, tanuló „az a különleges bánásmódot igénylö gyermek, tanuló, aki a szakértői bizottság szakértői véleménye alapján mozgásszervi, érzékszervi (látási, hallási), értelmi vagy beszédfogyatékos, több fogyatékosság együttes előfordulása esetén halmozottan fogyatékos, autizmus spektrum zavarral vagy egyéb pszichés fejlődési zavarral (súlyos tanulási, figyelem- vagy magatartásszabályozási zavarral) küzd". A sajátos nevelési igényü tanulók (SNI) atipikus fejlődésü gyerekek. Jellemző rájuk, hogy bizonyos agyi területeik éretlenek, illetve sérültek. Ebből adódóan a képességfejlődésük időben elhúzódik, így a nevelési folyamat során a pedagógiai szakaszok (korai fejlesztés, óvodai, iskolai, felnőttkori szakaszok) és azok feladatai módosulnak. Képességeik általában hosszabb időintervallum alatt alakulnak ki, és speciális sérülés miatt specifikus módszerek, eljárások alkalmazását követeli meg fejlesztésük. A nevelési folyamatnak ezért alkalmazkodnia kell a gyermekek egyéni sajátosságához, többlet időt kell biztosítani a képességek „beéréséhez”. Ennek jogi 
keretrendszere kiépült, az állam fokozott felelősséget vállal a fogyatékkal élők esélyegyenlöségének és teljes társadalmi integrációjának megvalósulásáért. A törvények, rendeletek lehetőséget biztosítanak a pedagógiai tevékenység sérülés specifikus adaptálására, így a környezeti akadályok felszámolása megvalósítható (Magyar Közlöny, 2012./132.) Az állam erőforrásokat biztosít a gyógypedagógiai - habilitációs - folyamatok megvalósításához (speciális iskolák, integrált nevelés, terápiás habilitációs és rehabilitációs tevékenység, egészségügyi ellátás, társadalmi érdekér-vényesítés (Csépe, 2008). Ez a feladat azonban nem csupán pedagógiai, hanem komplex társadalmi probléma is (Réthy, 2002). Az inkluzív (befogadó) oktatás szerint, az iskoláknak képessé kell válniuk minden gyermek, de különösen a sajátos nevelési igényü gyermekek szükségleteinek kielégítésére. Ezzel a rendelkezésselamennyiben teljesen megvalósulna, valóban minden gyermek már életének az elején megkapná a lehetőséget, hogy teljes jogú tagja legyen a társadalomnak. Cél, hogy a sajátos nevelési igényü gyerekek ne érezzék magukat kirekesztve az oktatásból.

Az integrációs folyamatok lényege, hogy az esélyegyenlőséget megteremtsék számukra, állapítja meg Mesterházi (2002). Minden törekvés ellenére a többségi iskolában tanító tanárok nem kedvelik az SNI tanulókat, mert felkészületleneknek érzik magukat az oktatásukhoz. Ezért lenne fontos a folyamatos továbbképzésük (Leite, 2012). Egy másik kutatás során Coskun (2009) azt figyelte meg, hogy a többségi pedagógusok nem kapnak elegendő központi támogatást. Gyakori, hogy a fejlődési egyenetlenségek a gyermekek számára nem okoznak problémát, csak a velük foglalkozó szülők, nevelők érzik a másságot. Ennek hatásaként azonban a gyermekben is kialakulhat a probléma-, betegségtudat, mint, ahogyan azt Glauber (2007) megállapítja. Maguk az érintett gyerekek szülei is óhatatlanul akadályt gördítenek gyermekeik sikeres fejlesztése elé. A valamilyen fogyatékossággal élő személyek nem illenek bele az ideális társadalomról alkotott képbe. Ez a szemlélet egyrészt beleivódik a szülők jelentős részének a gondolatai közé és ezért inkább szégyellve hanyagolják a sérült gyereküket; másrészt társadalmi szinten is az inkluzív szemlélet általános elterjedésének akadályává válik (Mazzag, 2013).

Magyarországon az SNI tanulók aránya a többségi tanulókhoz képest (1. táblázat) megegyezik Európa más országaiéval és az utóbbi években (2011-2015 között) lényeges változás nem is történt.

1. táblázat: SNI tanulók Magyarországon 2011-2015. évben (forrás: 2011-2015 KSH oktatási adatok alapján a Szerző)

\begin{tabular}{|c|c|c|c|}
\hline Tanév & $\begin{array}{c}\text { Összes általános iskolás } \\
\text { tanuló (fö) }\end{array}$ & SNI tanuló (fö) & SNI \% \\
\hline $2011 / 2012$ & 748000 & 52000 & 6,9 \\
\hline $2012 / 2013$ & 743000 & 51000 & 6,9 \\
\hline $2013 / 2014$ & 748000 & 52000 & 6,9 \\
\hline $2014 / 2015$ & 751320 & 52517 & 6,9 \\
\hline
\end{tabular}

\section{SNI tanulók a testalkati és motoros tudlajdonságok aspektusából}

Mivel jelen tanulmány az SNI-s tanulók testalkati, motoros tulajdonságaira fókuszál, itt kell szólnunk e tulajdonságokról is. A mindennapi életünkben és a közoktatásban is az utóbbi időkben egyre nagyobb jelentőséget tulajdonítanak a sporttudománnyal foglalkozó kutatók az aktív sporttevékenységnek és a testnevelés óráknak. Számos kutatás bizonyítja a fiatalkori 
rendszeres sportolás szükségességét (ezek egyik eredménye: a mindennapos testnevelés bevezetése Magyarországon a fiatalok harmonikus testi fejlődésének elősegítéséért).

Egy Egyesült Államokban 12-19 év közötti fiatalokon végzett keresztmetszeti vizsgálat során $(n=3110)$ a kutatók azt állapították meg, hogy a vizsgált fiatal fiúk 33,6 százalékának és a lányok 34,4 százalékának az alap állóképessége gyenge. Ennek oka az alacsony fizikai aktivitás, amely alacsony kardio-respiratorikus teljesítményt eredményez, amely meghatározza a későbbiek során a különböző keringési-légzési betegségek, illetve ezekből eredő halálozás előfordulását (Carnethon és tsai, 2005). A fizikailag aktívabb gyerekek jobb anyagcserével, kardio-respiratorikus funkciókkal, nagyobb állóképességgel rendelkeznek. A fizikailag aktív életmód és a jobb tanulmányi eredmények között pozitív a kapcsolat, mint ahogyan arra már több szerző is rámutatott. Egy amerikai vizsgálat összegezte 125 tanulmány vizsgálat eredményét 2007 évtől kezdődően: a vizsgálatok 95 százaléka megerősítette a pozitív kapcsolatot (Erin, 2012). A mozgásnak hatása van a mentális egészségre is. Egy 80 fős vizsgálat során a kutatók arra keresték a választ, hogy egy nyolchetes, heti kétszer másfél órás sportfoglalkozásnak milyen hatása van a kísérleti csoport mentális egészségére. A kísérlet végén mind a kontrol, mind a kísérleti csoport résztvevői kitöltöttek egy sztandardizált elégedettség mérő kérdőívet és szignifikáns különbséget találtak a két csoport teljesítménye között, a kísérleti csoport javára (Teymor, 2012). Fontos lenne az SNI-tanulók fizikai aktivitásának növelése, hiszen így a szellemi teljesítményük is javulna. Dicséretes, hogy Magyarországon egy egységes tanulói motoros mérést dolgoztak ki, amely alapján folyamatosan nyomon követhető az ifjúság fizikai állapota. A NETFIT (Nemzeti Egységes Tanulói Fittségi teszt) rendszert a Magyar Diáksport Szövetség dolgozta ki abból a célból, hogy az ifjúság az egészséghez szükséges fittségi állapotot elérje, megőrizze és fejlessze. A Magyar Közlöny 2014. október 27-én jelentette meg a 20/2012. (VIII.31.) EMMI rendelet, amely bemutatja a NETFIT-et, valamint szabályozza annak tartalmi kereteit. (Magyar Közlöny, 2012./132.) A mérési rendszert tudományos megalapozottsággal készítették el a tervezői, amely egy országosan egységes, diagnosztikai módszereken alapuló méréssorozatot jelent. A köznevelési intézmények a mérésekhez szükséges felszereléseket, oktatási anyagokat megkapták, sőt több helyen ingyenes továbbképzést is szerveztek a testnevelők számára, akik országosan mérik fel az összes diákot a 2015. január 5. és május 27. közé eső mérési időszakban. A NETFIT program természetesen az SNI tanulókat is érinti, hiszen ők is ugyanazokba az iskolákba járnak, mint többségi társaik. Vizsgálatomnak az volt a célja, hogy képet kapjak az SNI-tanulók testalkati mutatóinak és motoros képességeinek az állapotáról a többségi tanulókhoz képest.

\section{SNI és kortárs tanulók testalkati és motoros képeségeinek összehasonlító vizsgálata}

E tanulmány során egy budapesti általános iskola sajátos nevelési igényü (SNI) és kortárs tanulóit vizsgájuk, azzal a céllal, hogy összehasonlítsuk a sajátos nevelési igényü tanulók (kísérleti csoport: $n=80$ fö) testalkati mutatóit és motoros teljesítményét a többségi osztályok (kontroll csoport: $n=80$ fö) tanulóival nemenként és korcsoportonként. Az adatgyüjtés a fizikai képességek és a testalkati mutatók vizsgálatára vonatkozott, amelyeket a 2015. évben bevezetett NETFIT (Nemzeti Egységes Tanulói Fittségi Teszt) alapján végeztünk minden tanulónál. A felmérést az iskola testnevelés munkaközösség négy testnevelő tanára együtt végezte a felső évolyamon. Az alsó évfolyamon munkámat a tanítónők segítették. Ez a vizsgálat nem tartozott volna a munkájukhoz, segítségüket ezúton köszönöm. Alapfeltevésem $\left(\mathrm{H}_{0}\right)$ szerint a kísérleti és a kontrollcsoport tanulóinak testalkati mutatói és motoros képességei nem térnek el egymástól. 


\section{Minta}

A keresztmetszeti vizsgálatban 1-8 évfolyamos tanulók vettek részt $(n=160)$. A kísérleti csoportban $(n=80) 17$ fö SNI lány, 63 fö SNI fiú volt. Azok a tanulók alkották a sajátos igényü tanulók kísérleti csoportját, akiket a szakértői bizottság annak jelölt és így is szerepelnek a kísérleti iskola tanulói nyilvántartásában. A kontrollcsoportban $(n=80)$ hasonló nemek közötti eloszlásban ugyanennyi fö vett részt. A kontrollcsoport résztvevőit véletlenszerüen választottam ki a többségi tanulók közül.

A vizsgálatom során a tanulókat négy korcsoportba osztottam (1-2., 3-4., 5-6. és 7-8. osztályosok) Ez a felosztás követi a felmenő rendszerü általános és középiskolai sportversenyekét. Az életkort decimálisan adtam meg, négy korcsoportot különítettem el, mind az SNI, mind a többségi tanulóknál. (1-2.osztály, 3-4, osztály, 5-6 osztály, 7-8 osztály) Az 5-6. osztályos lányok között az iskolánkban összesen 2 fö SNI-tanuló lány található, ez pedig statisztikailag értékelhetetlen lett volna. Így abban a korosztályban nem végeztem méréseket. A vizsgálati mintát és életkoronkénti csoportjait az 2. táblázat tartalmazza.

\section{2. táblázat: A vizsgálatban résztvevö tanulók létszáma (forrás: a Szerzö)}

\begin{tabular}{|l|c|c|c|c|l|}
\hline \multirow{2}{*}{ Korcsoport } & \multicolumn{2}{|c|}{ Lányok (fö) } & \multicolumn{2}{c|}{ Fiúk (fö) } & \multirow{2}{*}{ Összesen } \\
\cline { 2 - 5 } & SNI & többségi & SNI & többségi & \multicolumn{1}{|c|}{} \\
\hline 1-2. osztály (7-8 év) & 6 & 6 & 20 & 20 & 52 \\
\hline 3-4. osztály (9-10) év & 6 & 6 & 20 & 20 & 52 \\
\hline 5-6. osztály (11-12 év) & 0 & 0 & 15 & 15 & 30 \\
\hline 7-8. osztály (13-14 év) & 5 & 5 & 8 & 8 & 26 \\
\hline Összesen & 17 & 17 & 63 & 63 & 160 \\
\hline
\end{tabular}

A vizsgálati minta az adott általános iskola SNI tanulóinak szempontjából reprezentatív, hiszen az összes odejáró SNI-tanulót bevontuk a vizsgálatba, így a vizsgált iskolára is vonhatok le következtetéseket - országos szintü reprezentativitáshoz azonban több intézményből verbuvált nagyobb tanulói mintaszámra lesz szükség a jövőben. Így jelen vizsgálat egy nagyobb mintaszámmal dolgozó, komplexebb vizsgálat elővizsgálatának tekinthető.

\section{Eszközök és eljárás}

2015. január elejére Magyarország összes általános iskolája megkapta a NETFIT méréshez szükséges összes felszerelést, könyvet, útmutató CD-t.

A vizsgálatban résztvevő tanulók mérését a központilag meghatározott időben - 2015 . február hónaptól kezdődően, 2015. május közepéig végeztük a testnevelő kollégákkal. Először a testalkati mutatók (BMI, testzsír százalékos aránya, vázizom százalékos aránya) mérése történt meg, majd a motoros tesztek felvétele következett.

Testalkati mutatók mérése: A NETFIT csomagban található Omron BF-508 Bioimpedanciaanalizátorral végeztük a testalkati mutatók mérését a következő változók figyelembe vételével:

- BMI vizsgálata: BMI (angolul body mass index, rövidítve BMI) egy olyan statisztikai mérőszám, mely az egyén testmagasságát és testtömegét hasonlítja össze. A kilogrammban megadott testtömeget osztjuk a méterben mért testmagasság négyzetével (Enkoyan, 2008). 
- Testzsír-százalék mérése: A készülék egy alacsony intenzitású elektromos áramot bocsát ki, amelyet az eltérü sürüségü szövetek eltérően vernek vissza. A készülék az eltérő jelekből következtet az emberi test testzsír és vázizom összetétel eltérésére. Ezeket az eredményeket rögzítettük. Sajnos a túl vékony gyerekek esetében a gép nem müködött, így ilyen esetekben adatokat nem szolgáltattunk. A kutatásban résztevő kísérleti és kontroll csoportba tartozó tanulók esetében ilyet nem tapasztaltunk.

- Vázizom-százalékos mérése: Mérési elve ugyanaz, mint a testzsír-százalék esetében.

Motoros tesztek: a testalkati mutatók mérését a motoros tesztek mérése követte - e mozgásos jellegü feladatok az alábbi gyakorlatokat tartalmazták:

- ingafutás,

- helyböl távolugrás,

- kézi szorítóerö,

- mellső fekvőtámaszban végzett karhajlítás-nyújtás,

- ízületi lazaság

- törzsemelés,

- felülés.

Jelen tanulmányban nem térünk ki a törzsemelés és a felülés eredményeinek elemzésére, mert ezek mérése során azt tapasztaltuk, hogy a gyerekek jelentős része maximális eredményt ért el a teljesítés során. Ez az SNI-tanulókra is vonatkozott. Természetesen, a méréseket elvégeztük és az összes tanulóról felvett adatot elküldtük a többi mérési eredménnyel együtt. Jelen cikknek nem feladata a NETFIT vizsgálati módszereinek bírálata, de az így kapott eredmények a többi vizsgálati eredményhez viszonyítva túlzóak.

A felvett adatokat Excell szoftver segítségével tároltuk és készítettük elő a statisztikai elemzéshez. Az adatok feldolgozása során az SPSS szoftvert használtuk, a statisztikai eljárások közül a kétmintás t-próbát alkalmaztuk.

\section{Eredmények}

A kísérleti (SNI-tanulók) és a kontrollcsoport (többségi tanuló) összefüggés vizsgálatának leíró statisztikáját a 3. táblázat összegzi. A különbségvizsgálat eredményei összefoglalva (csak a $\mathrm{p} \leq 0,05$ szinten szignifikáns különbségek közlésével):

1. A testalkati mutatók összefüggés vizsgálatának eredményei közötti különbségek az SNI tanulók csoportja és a kontrollcsoport között:

1.1. BMI (Body Mass Index): lányoknál és fiúknál is az 1-2. osztályosak esetében találtunk különbséget - az SNI csoport BMI értéke szignifikánsan nagyobb.

1.2. Testzsír százalékos aránya: az 1-2. osztályos, illetve a 3-4. osztályos lányok között, valamint a 7-8. osztályos fiúk között találtunk szignifikáns különbséget - az SNI tanulók értékei nagyobbak.

1.3. Vázizom százalékos aránya: az SNI tanulók érékei alacsonyabbak, mint a kortársaikra jellemző értékek a 3-4. osztályos lányok, és az 1-2., 5-6. és 7-8. osztályos fiúk esetében.

2. A motoros mutatók összefüggés vizsgálatának eredményei közötti különbségek az SNI tanulók csoportja és a kontrollcsoport között:

2.1. Ingafutás: az 1-2. és a 3-4. osztályos SNI fiúk ingafutásbeli eredményei szignifikánsan alacsonyabbak, mint a kortárs fiúké.

2.2. Helyböl távolugrás: az 1-2. és a 3-4. osztályos lányok, illetve az 1-2., a 3-4. és 5-6. osztályos fiúk közötti különbség szignifikáns - az SNI tanulók által elért értékek alacsonyabbak. 
3. táblázat: leíró statisztika és csoportok közötti különbségek (a cellák csoportátlagokat jelölnek zárójelben a szórás értékekkel, a kétmintás t-próba által jelzett $p \leq 0,05$ szinten szignifikáns csoportok közötti különbségek dölt betüvel kiemelve - forrás: a Szerzö)

\begin{tabular}{|c|c|c|c|c|c|c|c|}
\hline Nem & & Változók & Csoport & 1-2. évfolyam & 3-4. évfolyam & 5-6. évfolyam & 7-8. évfolyam \\
\hline \multirow{16}{*}{ 产 } & \multirow{6}{*}{ 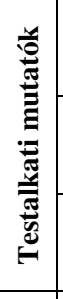 } & \multirow{2}{*}{ BMI } & SNI & $19,05(3,57)$ & $19,41(3,48)$ & - & $20,08(4,82)$ \\
\hline & & & Kontroll & $15,28(1,26)$ & $16,08(1,46)$ & - & $19,94(0,78)$ \\
\hline & & \multirow{2}{*}{ Testzsír \%-os aránya } & SNI & $23,30(8,19)$ & $23,83(8,48)$ & - & $20,18(13,15)$ \\
\hline & & & Kontroll & $12,30(6,35)$ & $10,78(4,66)$ & - & $20,42(2,97)$ \\
\hline & & \multirow{2}{*}{ Vázizom \%-os aránya } & SNI & $29,98(2,34)$ & $31,46(1,82)$ & - & $33,14(4,16)$ \\
\hline & & & Kontroll & $31,63(2,59)$ & $35,73(1,37)$ & - & $35,30(0,97)$ \\
\hline & \multirow{10}{*}{ 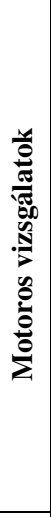 } & \multirow{2}{*}{ Ingafutás } & SNI & $15(6,32)$ & $22,33(14,63)$ & - & $29,80(12,69)$ \\
\hline & & & Kontroll & $24,83(9,34)$ & $39,16(11,94)$ & - & $33,40(10,09)$ \\
\hline & & \multirow{2}{*}{ Helyből távolugrás } & SNI & $98,83(13,27)$ & $126,66(21,75)$ & - & $147,20(26,66)$ \\
\hline & & & Kontroll & $129,66(12,8)$ & $154,16(12,57)$ & - & $175,60(6,26)$ \\
\hline & & \multirow{2}{*}{ Kézi szorítóerő } & SNI & $11,46(3,96)$ & $13,81(2,63)$ & - & $24,30(3,37)$ \\
\hline & & & Kontroll & $11,08(2,24)$ & $15,63(1,75)$ & - & $29,78(5,74)$ \\
\hline & & \multirow{2}{*}{$\begin{array}{l}\text { Mellső fekvőtámaszban végzett } \\
\text { karhajlítás-nyújtás }\end{array}$} & SNI & $2,33(2,80)$ & $6,50(5,75)$ & - & $8,80(9,62)$ \\
\hline & & & Kontroll & $11,5(7,09)$ & $19(7,45)$ & - & $7,6(2,96)$ \\
\hline & & \multirow{2}{*}{ Ízületi lazaság } & SNI & $25,91(9,49)$ & $23,63(8,15)$ & - & $22,92(7,88)$ \\
\hline & & & Kontroll & $29,53(6,18)$ & $35,31(7,66)$ & - & $37,78(4,21)$ \\
\hline \multirow{16}{*}{ Fiúk } & \multirow{6}{*}{ 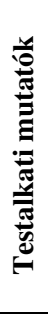 } & \multirow{2}{*}{ BMI } & SNI & $17,53(3,49)$ & $18,84(2,74)$ & $21,19(4,97)$ & $21,61(5,68)$ \\
\hline & & & Kontroll & $15,68(1,27)$ & $17,89(3,20)$ & $19,40(4,39)$ & $18,83(3,94)$ \\
\hline & & \multirow{2}{*}{ Testzsír \%-os aránya } & SNI & $18,95(6,98)$ & $20,50(6,72)$ & $22,85(7,72)$ & $20,12(10,28)$ \\
\hline & & & Kontroll & $15,46(3,53)$ & $18,06(7,07)$ & $17,68(8,54)$ & $12,22(6,13)$ \\
\hline & & \multirow{2}{*}{ Vázizom \%-os aránya } & SNI & $29,53(4,03)$ & $34,62(2,39)$ & $34,94(2,34)$ & $35,00(4,54)$ \\
\hline & & & Kontroll & $31,89(3,25)$ & $34,12(2,93)$ & $37,11(3,03)$ & $38,93(3,95)$ \\
\hline & \multirow{10}{*}{ 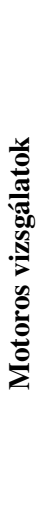 } & \multirow{2}{*}{ Ingafutás } & SNI & $15,25(7,31)$ & $18,35(13,49)$ & $23,20(13,95)$ & $40,37(27,25)$ \\
\hline & & & Kontroll & $29,45(10,71)$ & $36,15(13,59)$ & $30,33(18,43)$ & $55,75(19,20)$ \\
\hline & & \multirow{2}{*}{ Helyből távolugrás } & SNI & $117,05(22,89)$ & $135,50(26,60)$ & $134,20(23,97)$ & $144(35,74)$ \\
\hline & & & Kontroll & $137,55(24,39)$ & $157,25(12,91)$ & $155,00(19,43)$ & $167,62(17,59)$ \\
\hline & & \multirow{2}{*}{ Kézi szorítóerő } & SNI & $10,57(3,47)$ & $16,23(2,84)$ & $21,18(4,43)$ & $25,36(8,57)$ \\
\hline & & & Kontroll & $13,94(3,31)$ & $16,54(3,06)$ & $21,22(6,04)$ & $27,97(5,18)$ \\
\hline & & \multirow{2}{*}{$\begin{array}{l}\text { Mellső fekvőtámaszban végzett } \\
\text { karhajlítás-nyújtás }\end{array}$} & SNI & $4,25(2,53)$ & $7,90(4,15)$ & $8,13(5,39)$ & $10,50(6,78)$ \\
\hline & & & Kontroll & $20,25(10,27)$ & $18,80(7,07)$ & $15,00(9,28)$ & $21,75(8,17)$ \\
\hline & & \multirow[t]{2}{*}{ Ízületi lazaság } & SNI & $18,59(5,90)$ & $23,43(7,51)$ & $19,19(6,75)$ & $16,60(5,08)$ \\
\hline & & & Kontroll & $24,49(4,57)$ & $22,86(4,83)$ & $21,88(4,50)$ & $21,25(5,05)$ \\
\hline
\end{tabular}

2.3. Kézi szorítóerő: az 1-2. osztályos fiúk esetében szignfikáns a különbség (az SNI fiú tanulók kézi szorítóereje kisebb, mint a kortás fiúké).

2.4. Mellső fekvőtámaszban végzett karhajlítás-nyújtás: lányoknál az 1-2. osztály és a 3-4. osztály esetében; fiúknál az 1-2., 3-4., 5-6. és 7-8. osztály esetében találtunk szignifikáns különbséget a csoportok között. Minden esetben az SNI tanulókra jellemző érték az alacsonyabb. 
2.5. Ízületi lazaság: a 3-4. és 7-8. osztályos lányok, valamint az 1-2. osztályos fiúk kísérleti és kontrollcsoportjai között volt a különbség szignifikáns (az SNI tanulókra jellemző értékek az alacsonyabbak).

\section{Megvitatás}

A kapott eredmények alapján elvethető az a felvetés, miszerint az SNI tanulók és a kortársaikból szervezett kontrollcsoport tanulóinak testalkati mutatói és motoros képességei nem térnek el egymástól. Úgy tünik, hogy a sajátos nevelési igényü tanulók testalkati mutatóikban és motoros képességeikben is különböznek a többségi társaiktól. Egy korábbi vizsgálatnak (Erdei, 2014) az volt a célja, hogy összehasonlítsa a sajátos nevelési igényü tanulók fizikai teljesítményét két eltérő pedagógiai programmal rendelkező általános iskolában. A kísérleti iskola SNI tanulóit a heti testnevelés órák mellett egy testnevelő tanár, alapozó terápiás végzettséggel heti két alkalommal 45 percen keresztül külön fejlesztette, míg a kontroll iskolában nem kaptak az SNI tanulók külön fejlesztést. Az alapozó terápiás foglalkozások hatására mérhető volt a különbség a két iskola tanulóinak fizikai teljesítménye között: a fejlesztett tanulók értek el jobb eredményeket. Egy másik kutatásban a finom mozgásokat fejlesztő berendezéssel (Wii) végzett vizsgálat során a kutatók hasonló eredményre jutottak. A kísérleti csoportba tartozó enyhén értelmi fogyatékos gyerekek finom mozgásai pontosabbak lettek, miután több héten keresztül fejlesztették őket a készülékkel a kontrollcsoporthoz képest. Az alkalmazott játékeszköz kiválóan stimulálta a vizuális területet és remekül fejlesztette a mozgáskoordinációt (Sáringerné, 2012). A sajátos nevelési igényü gyerekek mozgatómezője és idegi kapcsolatai eltérően strukturáltak normál társaikhoz képest. Az ilyen tünetekkel küzdő gyerekek agyi éretlenségének, illetve sérülé-sének pato-fiziológiás mechanizmusa még nem teljesen ismert. Számos vizsgálatot végeztek radiológiai módszerekkel (CT, MRI), így próbálták azonosítani a sérült, illetve másként múködő agyi területeket. A kutatók szerint van különbség a sérült és az egészséges agyú gyerekek azonos agyterületeinek müködése között (Elizabeth, 2014). Amennyiben ez az eltérés a mozgatómezőt érinti, az koordinációs zavart jelent a mozgásukban, amelyhez az esetek jelentős részében alulkondicionáltság is társul. A kortikális és szubkortikális agyi területek fejlettsége és a mozgás-gyakorlás együttesen határozzák meg a motoros képességeket. A koordinációs képességek adják a sportképességek hátterét, ezért fontos a korai életszakaszban a fejlesztésük. Azonban, ha ezeknek a képességeknek a fejlesztése elmarad, a kondicionális képességek fejlesztése sem lesz megvalósítható (Tóth, 2006). Amennyiben a testnevelés oktatásban nem történik olyan változtatás, amely előnyösen - a képességeik és lehetőségeik figyelembevételével - érintené az SNI-tanulókat, abban az esetben köztük és a többségi tanulók közötti testalkati és motoros teljesítménybeli különbségek fennmaradhatnak.

\section{Korlátozások}

A NETFIT mérést a 2014/2015. tanév második félévétől kezdődően az ország összes 5-8. évfolyamon tanuló diákján kell végrehajtani. Azonban jelen tanulmány elkészítése során az alsóbb évfolyamos (1-4. évfolyam) gyerekeket is lemértem ugyanazokkal az eszközökkel és módszerekkel. Nincsen adat arról, hogy más általános iskolában is lemérték volna az alsó tagozatos tanulókat. A vizsgálati minta a bevont általános iskola SNI tanulóinak szempontjából reprezentatív, hiszen az összes idejáró SNI-tanulót vizsgáltuk, így elsősorban a vizsgált iskolára vonhatunk le következtetéseket. Az országos szinten is reprezentatívnak tekinthető eredményekhez átfogóbb mintára lesz szükség a jövőben.

E vizsgálat nem terjed ki a NETFIT teljes mérési anyagára, hiszen (a korában említett plafon-effektus miatt) nem vettük figyelembe a felülés és a hasonfekvésben végzett törzsemelések eredményeit. 
Az alsó évfolyamon a vizsgálatot mindkét korcsoportban (1-2. és 3-4. osztályok) el tudtam végezni. Felső évfolyamon az 5-6. osztályos lányok között összesen 2 fö SNI-tanuló volt, így statisztikailag értékelhető eredményt nem várhattam. Érdekes lett volna összehasonlítani, az alsó és a felső évfolyamok közötti különbséget. A cikk csak sejteni engedi, de alátámasztani nem tudja, hogy a felső évfolyamokra az SNI-tanulók a többségi tanulókhoz képest már kevesebb esetben mutatnak szignifikáns különbséget. Szintén nyitott maradt a kérdés és további kutatásokat ösztönözhet annak eldöntése, hogy ez vajon a tanítók-tanárok módszertani különbözősségének tudható-e be, vagy az SNI-tanulók idegrendszerének érési folyamatáról van szó?

\section{Konklúziók}

Testalkati mutatók összefüggés vizsgálat eredményei: az SNI lányoknál a vizsgált 3 korosztály esetében összesen 4, az SNI fiúknál a vizsgált 4 korosztály esetében összesen 5 esetben tapasztaltam szignifikáns különbséget a többségi tanulókhoz képest.

A motoros mérések összefüggés vizsgálat eredményei: az SNI lányoknál a vizsgált 3 korosztály esetében összesen 6, az SNI fiúknál a vizsgált 4 korosztály esetében összesen 11 esetben tapasztaltam szignifikáns különbséget többségi tanulókhoz képest. Mindkét nemnél és minden mérésnél az SNI-tanulók gyengébben teljesítettek.

Az SNI tanulók más tantárgyból több külön foglalkozást is kapnak, mint kortársaik és figyelembe véve a későbbi „érésüket”, ez kifizetődőnek tünik. Több fejlesztő terápiát dolgoztak ki a különböző sérülésekkel, tanulási zavarokkal küzdő gyerekek számára, amelyek bizonyítottan jó hatással vannak nem csak a motoros, hanem a kognitív képességeikre is (Keresztesi és Marton, 1999; Gkouni és tsai, 2011; Malekian, 2013). Noha tudjuk, hogy a testnevelő tanárok és a fejlesztő pedagógusok a tanulók motoros képességein keresztül a tanulók értelmi képességeiket is fejlesztik, egyet kell értenünk Bánfalvy (2009) megállapításával, miszerint Magyarországon az általános iskolákban az oktatáshoz a személyi feltételek nem teljesen adottak. Magyarországon, alsó tagozaton a testnevelés órák 10,8\%-át tartják testnevelő tanárok. Ennek okát a cikk szerzője sem tárta fel, csak valószínűsíti, hogy ugyanúgy munkaerő-gazdálkodási, mint szervezési jellegü problémák húzódhatnak a háttérben (Gergely, 2002). Erre példa lehet egy olyan általános iskola esete, melyben a testnevelő tanárok egyáltalán nem tanítanak alsó tagozaton, mert a tanítók kötelező heti óraszáma csak úgy biztosított, hogy a testnevelés tárgyat is ők tanítják. Egy korábbi tanulmány is alátámasztja azt a tényt, hogy a testnevelő szaktanárok jobb teljesítményt érnek el a tanulóknál a tanító végzettségüekkel szemben, mivel inkább teljesítmény orientáltabbak, gazdagabb a testi-motoros fejlesztést érintő pedagógiai eszközrendszerük (Andreas, 2008). Eredményeink arra utalnak, hogy az SNI gyerekek nevelése-oktatása során sokkal nagyobb hangsúlyt kellene fordítani a testnevelés oktatására, illetve a fejlesztésükre, hiszen mérhetően kimutatható volt, hogy motoros teljesítményeik és testalkati mutatóik rosszabbak a többségi tanulóknál. A cél ezeknek a gyerekeknek a felzárkóztatása, ami sikeresebb lehet szakemberek bevonásával.

\section{Irodalom}

Andreas, P. (2008). A motorikus teljesítmény változása általános iskolás fiúknál: tanítószaktanár összehasonlítás. Magyar Sporttudományi Szemle, 2008/2, 26-29.

Bánfalvy Cs. (2009). A fogyatékos emberek iskolai integrációjáról. Esély, 2009/2, 3-15.

Carnethon, M.R., Gulati,M. és Greenland.P. (2005).Prevalence and cardivascular disase correlates of low cardiorespiratory fitness in adolescents and adults. JAMA (The Journal of the American Medical Association), 294/23. 2981-2988.

Coskun, O. (2009). Classroom teacher's styles of using and development materials of inclusive education. Procedia Social and Behavioral Sciences, 1 , 2758-2762. 
Csépe V. (2008). A különleges oktatást, nevelést és rehabilitációs célú fejlesztést igénylö (SNI) gyermekek ellátásának gyakorlata és a szükséges teendők. Zöld könyv a magyar közoktatás megújitásáért. Országos Közoktatási Intézet, Budapest.139-165.

Elizabeth, S. N. (2014).Functional neuroanatomical evidence for the double-deficit hypothesis of developmental dyslexia. Neuropsychologia, 61, 235-246.

Enkoyan, G. (2008).Adolphe Quetelet (1796-1874) - The average man and indices of obesity.

Nephrology Dialysis Transplantation, 47-5.

Erdei N. (2014). Sajátos Nevelési Igényü tanulók összehasonlító vizsgálata két általános iskolában. Acta Agraria Debreceniensis, 58.71-76.

Erin, K. (2012). Physical activity and academic achievement in children: A historical perspective. Journal of Sport and Health Science , 1,160-169.

Gergely Gy. (2002).A testnevelés tantárgy helyzete és fejlesztési feladatai. Új pedagógiai szemle, 2002, júl-aug. 161-174.o.

Gkouni, V. (2011).The efficacy of teaching differentiation on children with Special Educational needs (SEN) through literature. Procedia Social and Behavioral Sciences, 29. 67-74.

Glauber, A. (2007). Az egészséges gyermek fejlödése, harmonikus fejlödés gyermekkorban. Inkluzív nevelés - A tanulók hatékony megismerése. Kézikönyv a pedagógusképzö intézmények részére. SuliNova Kiadó, Budapest.

Keresztesi K. és Marton. É. (1999). Alapozó Terápia. Fejlesztő Pedagógia (Preparatory therapy. Developing Pedagogy Special Issue, 1999. 80-105.

Leite, S. (2012). Dyslexia through the eyes of primary school teachers. Procedia Social and Behavioral Sciences, 69.41-46.

Magyar Közlöny 2012. évi 132. Szám Az emberi erőforrások miniszterének 32/2012. (X. 8.) EMMI rendelete a Sajátos nevelési igényü gyermekek óvodai nevelésének irányelve és a Sajátos nevelési igényü tanulók iskolai oktatásának irányelve kiadásáról 22436-22525.

Magyar Közlöny 2012. évi 115. Szám Az emberi erőforrások miniszterének 20/2012. A nevelési- oktatási intézmények müködéséről és a köznevelési intézmények névhasználatáról. 19524.

Malekian, T. (2013). Investigating The effect of multi-sensory games on decrease of male students' dyslexia (based on Goodman theory) specified for elementary school second grade in Aligudarz city. Procedia Social and Behavioral Sciences, 82. 796-802.

Mesterházi Zs. (2002). Integrált nevelés a nemzetközi és a hazai oktatásrendszerben. Gyógypedagógiai Szemle, 2002/ 1. 10-12.

Réthy E. (2002).A speciális szükségletü gyermekek nevelése, oktatása Európában. Magyar Pedagógia ,102.( 3). 281-300.

Sáringerné Szilárd Zs. (2012).A Wii játék fejlesztő hatása az értelmi sérültek körében. Gyógypedagógiai Szemle, 2012/2. 188-195.

Teymor, A. (2012).The effect of the selected exercise on male students' happiness and mental health. Procedia - Social and Behavioral Sciences, 46. 2702 - 2705.

Tóth L. (2006). A motoros képességek fejlődése serdülőkorban. Kalokagathia. XLIV. 223235.

KSH oktatási adatok 2012/2013. Letöltés: 2015.11.11. Web: http://www.ksh.hu/docs/ hun/ xftp/idoszaki/oktat/oktatas1213.pdf

KSH oktatási adatok 2014/2015. Letöltés: 2015.11.11. Web: https://www.ksh.hu/docs/hun/ xftp/idoszaki/oktat/okt1415.pdf 